\title{
14. Beneath the Billabongs: The scientific legacy of Robert Rush Miller ${ }^{1}$
}

\section{Gifford Hubbs Miller and Robert Charles Cashner}

Robert 'Bob' Rush Miller was born in the state of Colorado on 23 April 1916, but he grew up in California, where from an early age he became interested in hot, dry places, and spent long hours in the desert southwest of the United States. Although his father, Ralph Gifford Miller, was a lawyer, as dictated by his own father, Ralph was more interested in natural history and took his sons on many backcountry trips, always wanting to go 'where the foot of man has never trod'. Bob was intrigued by the geology of the desert, and initially planned to be a geologist, but his discovery of tiny fishes living in the most remote and isolated desert springs galvanised his interest in zoology. Bob's fascination with fish began in earnest as an undergraduate on a Pomona College geology field trip to the Mohave Desert. There, in the lowermost permanent flow of the Mohave River, Bob saw small fishes. He questioned his professor about their identity and why they were present in the desert. The professor had no answers, so Bob collected some of the fish with his hat and took them back to Pomona for study. His passion for collecting in the most remote and inhospitable settings and his demand to understand the origin of tiny desert fishes won the attention of faculty at the University of California, Berkeley. He transferred from Pomona College to Berkeley after his sophomore year, and completed his undergraduate degree there in 1939. On one expedition looking for fish in Death Valley with his father while still an undergraduate, he sank his mother's Buick in mud. After collecting the fish he sought, Bob tried unsuccessfully for two hours to dislodge the car. By then it was $48^{\circ} \mathrm{C}$, and, cautioning his father to stay under the car, he set forth to get help on the highway, about $3 \mathrm{~km}$ away. He collapsed of sunstroke and dragged himself to the road just as a rare car came by and rescued him from certain death. He quickly returned to save his father, and his mother's precious Buick.

These stories of dedicated fish collecting reached Carl Hubbs, renowned ichthyologist specialising in the fishes of the arid American west, who was then at the University of Michigan. Hubbs invited Bob to join his crew on a field expedition during the summer of 1938. He had been collecting fish in the western United States with his family for many years, and, to maintain enthusiasm for the arduous expeditions, Hubbs offered his three children a bounty of five cents

1 This chapter was greatly aided by research and details of Dr Robert Rush Miller's life compiled by his daughter, the late Frances M. Cashner. 
a piece for each species collected, one dollar for a new species and five dollars for a new genus. Bob Miller first met Hubbs and his family at a campsite in Nevada, where he was shocked to see the famous ichthyologist dressed like a tramp. But he immediately fell in love with Hubbs' daughter, nineteen-year-old Frances, and proposed to her two weeks later. The following year, Bob accepted Hubbs' offer of graduate work at Michigan (see Figure 14.1), where he completed his PhD in 1944 and subsequently accepted an appointment as Assistant Curator of Fishes at the Smithsonian Institution's National Museum of Natural History. In those days, the saying was 'join the Smithsonian and see the world'. He began his tenure at the Smithsonian with an extended field expedition to Guatemala in 1946.

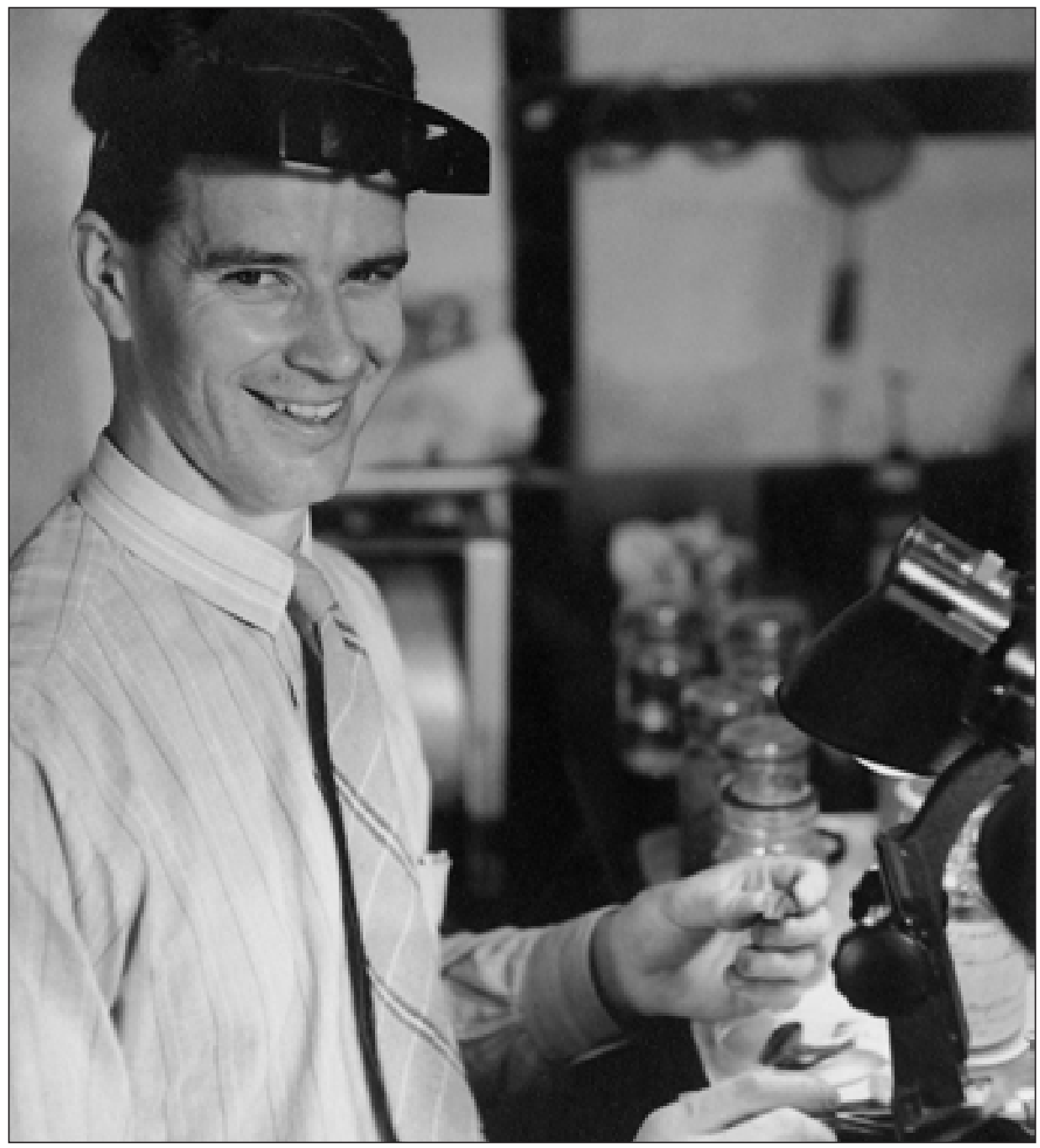

Figure 14.1 Miller at his microscope while finishing his $\mathrm{PhD}$ at the University of Michigan, 23 May 1944

By permission of the Estate of R. R. Miller. 
When the Australian ethnologist and photographer Charles Pearcy Mountford was in the United States in 1945 on a lecture tour, sponsored by the Australian Government, the National Geographic Society offered to support a research project of Mountford's choosing (see Jones and May, this volume). As the plan for an expedition to Arnhem Land gained momentum, the Smithsonian decided to commit four members of staff. They were archaeologist Frank M. Setzler, mammalogist David H. Johnson, ornithologist Herbert G. Deignan, and Robert R. Miller - one of the Expedition's youngest members, as the ichthyologist. Bob left Frances and their two small children in California with her parents, Carl and Laura Hubbs. Carl had recently accepted a post at the Scripps Institution of Oceanography in La Jolla, California. In February 1948, Bob Miller departed from San Francisco for 10 months in Australia.

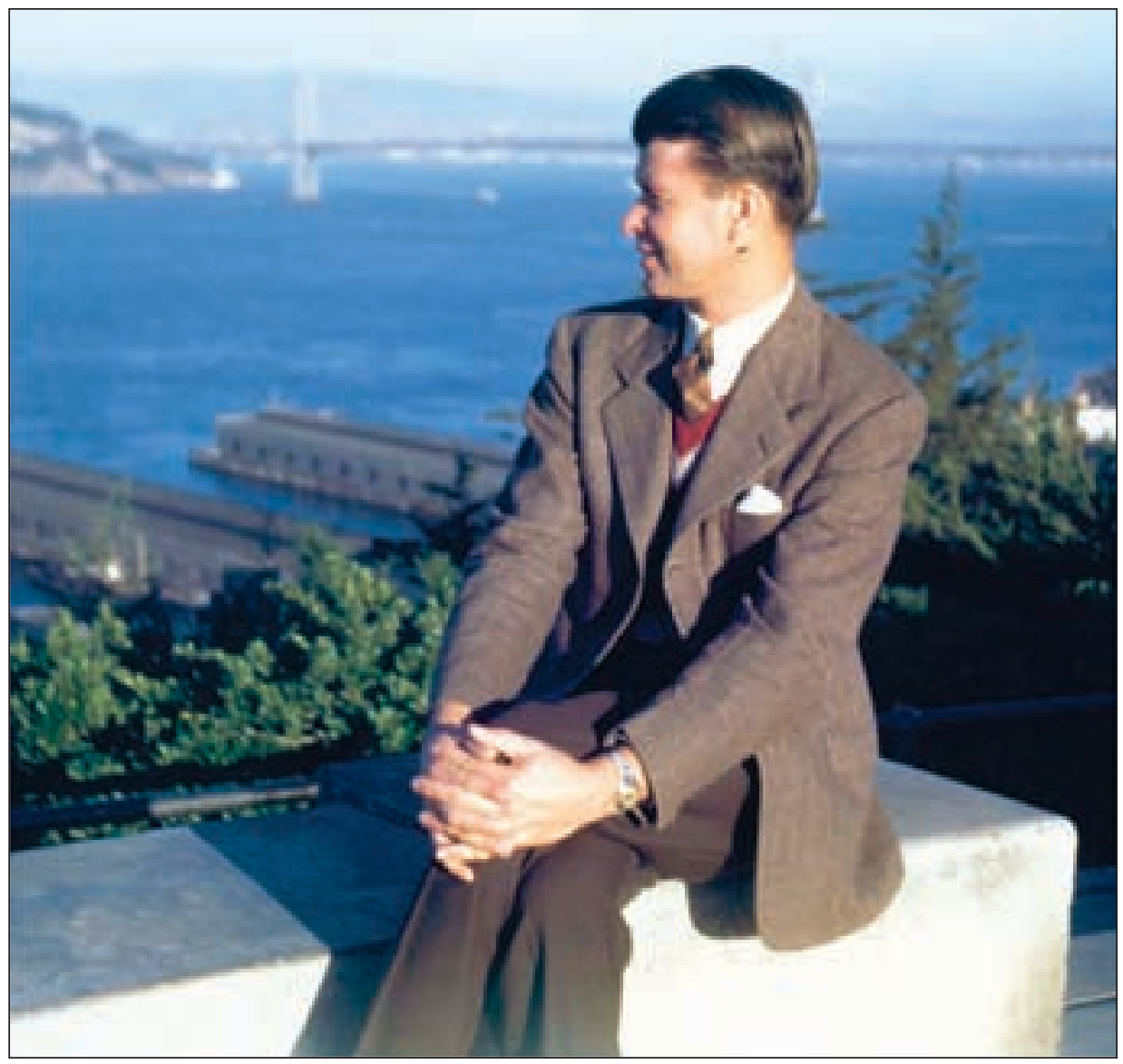

Figure 14.2 Miller just before departing San Francisco for Australia and the Arnhem Land Expedition in February 1948

Photograph by Frances Hubbs Miller. By permission of the National Library of Australia. nla.gov.au/nla. pic-vn4511010. 
Already well known as a tenacious collector, Bob lived up to his reputation on the Arnhem Land Expedition. If there had been a contest to determine who could collect the most specimens, Bob Miller would have won, with more than 30000 fish specimens - a number far higher than any other collector of 'things'. Bob's dedication to being certain that he had collected a complete record of all fish that lived within a specific habitat was caricatured by the well-known Australian artist Eric Jolliffe (see Figure 14.3), who joined the Expedition for 10 days in July 1948 during their stay at Yirrkala. Bob not only collected fish, he also had a life-long interest in herpetology, and was unable to resist collecting in that field as well (see Figure 14.4). ${ }^{2}$

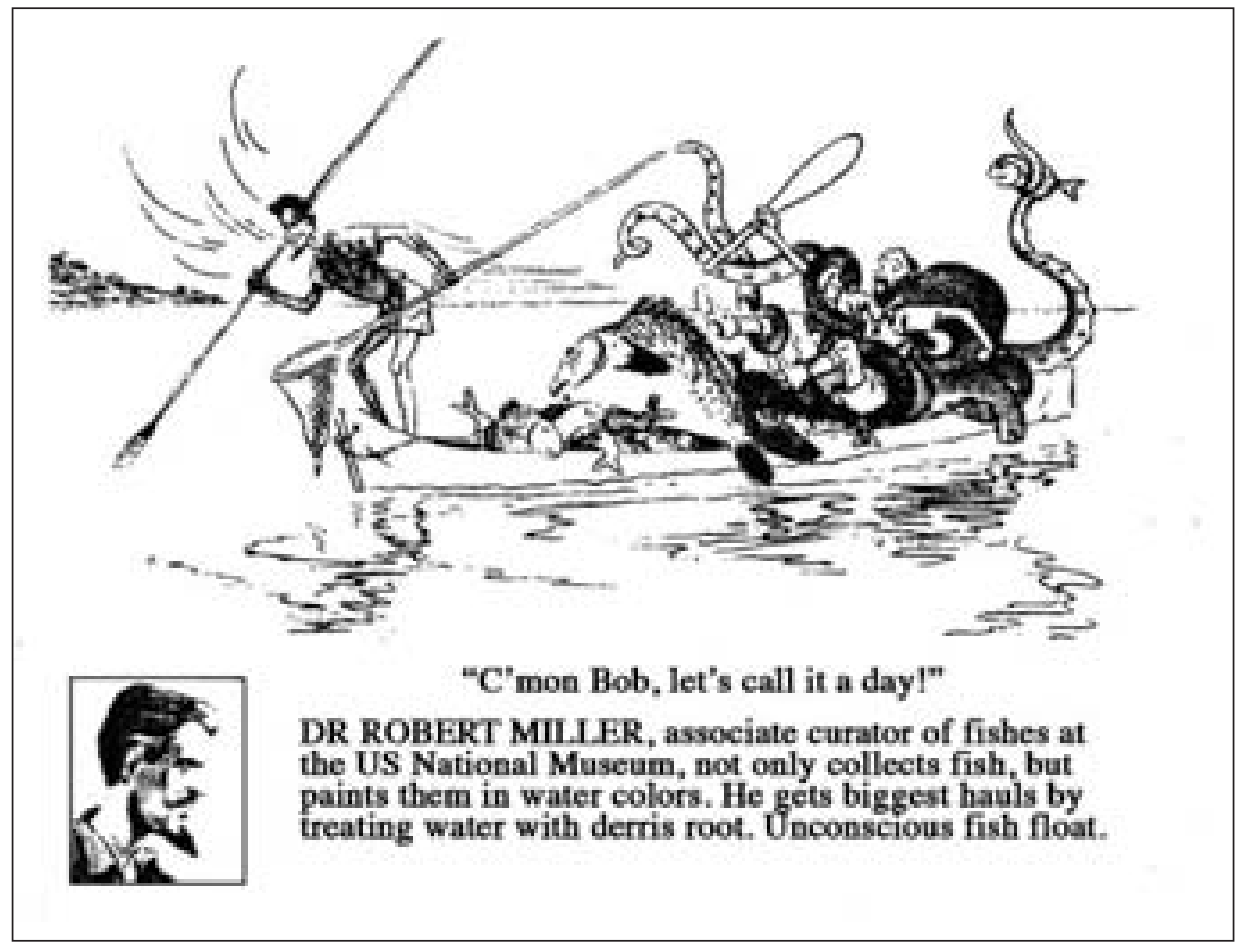

Figure 14.3 Cartoon of Robert Rush Miller by Eric Jolliffe, which illustrates the persistent collecting style that characterised Miller's field research for his entire career

By permission of the estate of R. R. Miller.

2 Personal photographs taken by Robert Rush Miller during the Arnhem Land Expedition: < http://nla.gov. au/nla.pic-vn4473516> (viewed 20 October 2010). His personal diaries are archived as Papers of Robert Rush Miller, 1947-51, MS 10053, National Library of Australia, Canberra. 


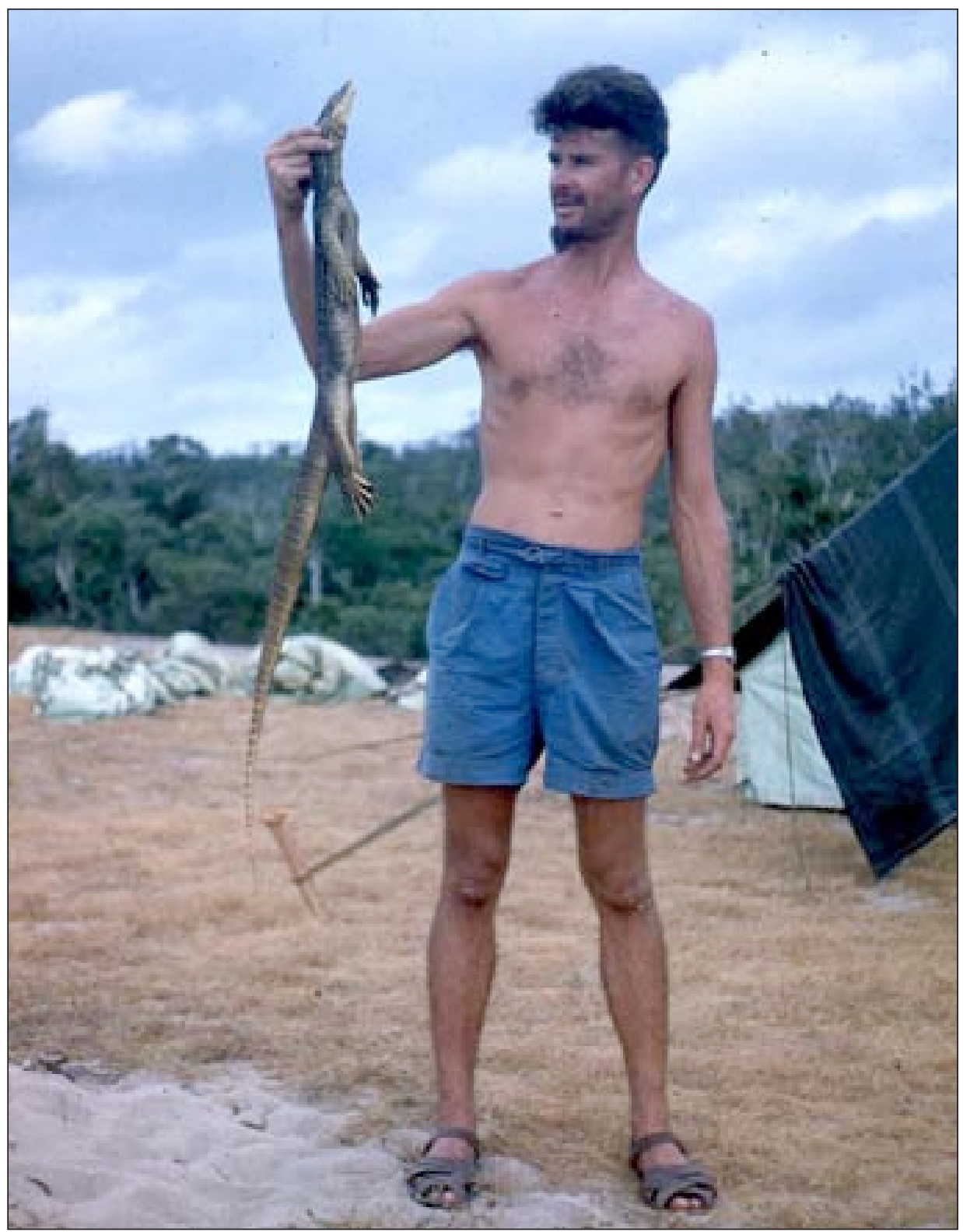

Figure 14.4 Miller as herpetologist, Arnhem Land, 1948

Photograph by a member of the Expedition. By permission of the Estate of R. R. Miller.

Of course, Arnhem Land presented numerous challenges to the collection of its fish fauna. And to meet this challenge, Bob employed a wide range of strategies to ensure he acquired a representative sampling of the fishes living in the country, including what the locals were eating. Many of his collections involved the copious use of various poisons: 'collection made with 40 pounds of barbasco 
root'; 'collection made with 35 pounds of derris root'; 'pool...a few inches deep...collection made by one-fourth pound of derris root... water temperature $100^{\circ} \mathrm{F}^{\prime}$; 'collected in the billabong... with a total of 25 pounds of rotenone'. Other methods were also employed when the conditions were appropriate-'a few fish shot with dust pistol'; 'collection made by hand'; 'collection by threeprong spear'; 'collection by night light and dipnet' — and of course Bob used more conventional methods, too: 'collection made by hook and line and spear'; 'collected by trolling'; 'collected in the billabong... with a gill net 125 feet [38 $\mathrm{m}]$ long' ${ }^{3}$

In his collecting, Bob was assisted by many helpers - from members of the Expedition to local Aboriginal people, including children tagging along for the fun (see Figures 14.5 and 14.6). But he was aided especially by Gerry Blitner, from Groote Eylandt, who accompanied him on many outings, and the two became firm friends (see Figure 14.7). In collecting fish by treating small water bodies with a poison that primarily kills fish and is harmless to humans, Bob quickly became popular with the local Aboriginal communities, because unwanted fish could be eaten (see Figure 14.8).

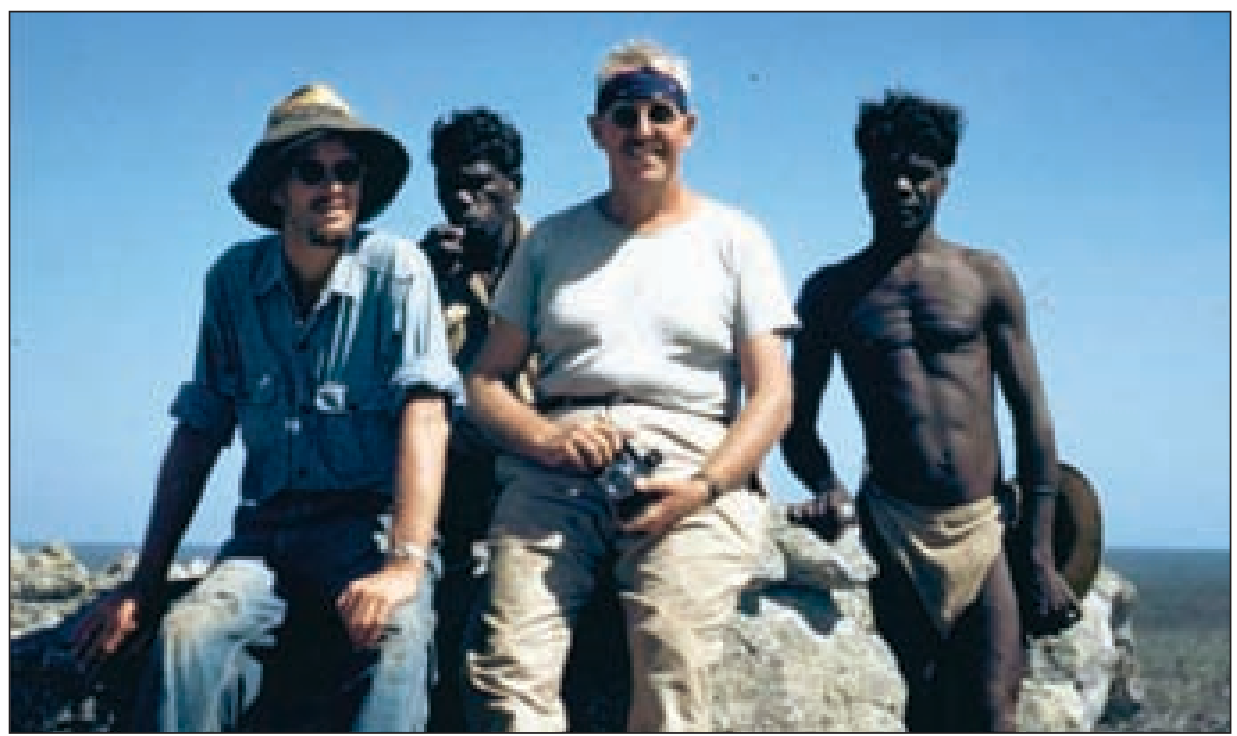

Figure 14.5 Miller, Frank Setzler and the men known to them as Kumbiala and Quartpot on Central Hill, Groote Eylandt, 25 May 1948

Photograph by Frederick McCarthy. By permission of the National Library of Australia. nla.pic-vn4494298.

3 All from field notes cited by Taylor, W. R. 1964, 'Fishes of Arnhem Land', in R. Specht (ed.), Records of the American-Australian Expedition to Arnhem Land. Volume 4: Zoology, Melbourne University Press, Carlton, Vic., pp. 45-307. 


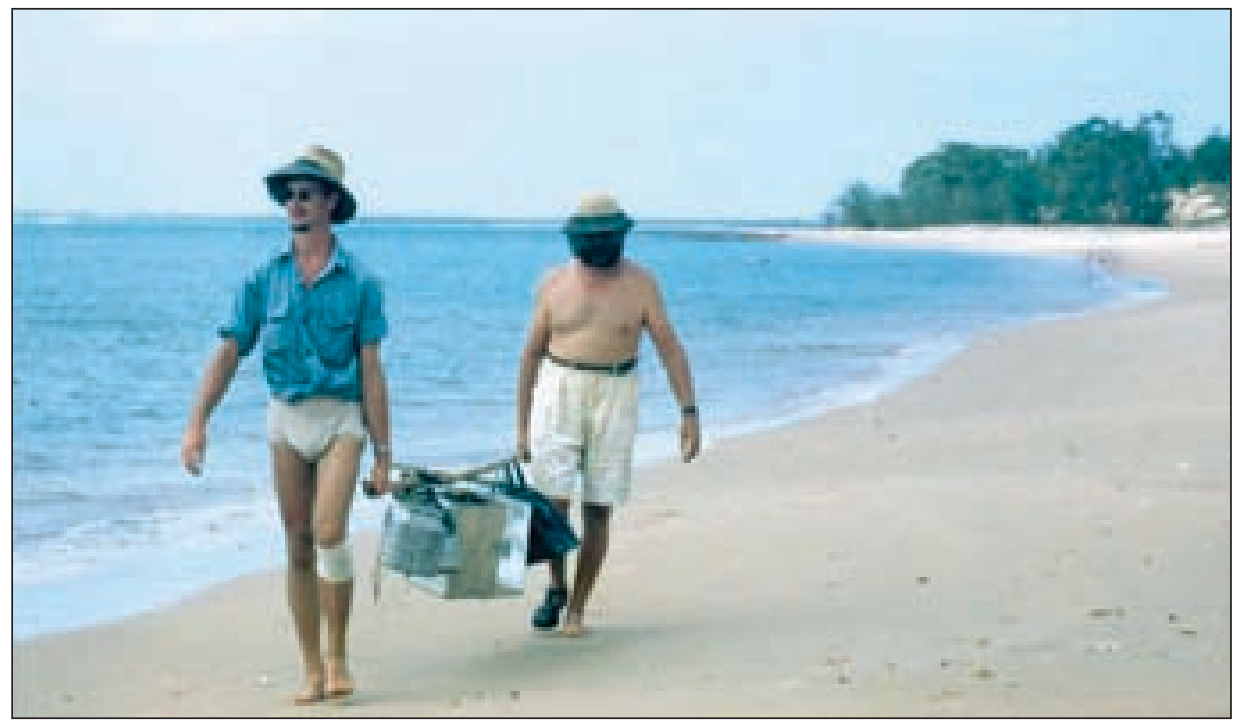

Figure 14.6 Bob Miller and Frank Setzler on the way to Second Reef near Port Langdon, Groote Eylandt, Northern Territory, 25 April 1948

Photograph attributed to Peter Bassett-Smith. By permission of the National Library of Australia. nla. pic-vn4494255.

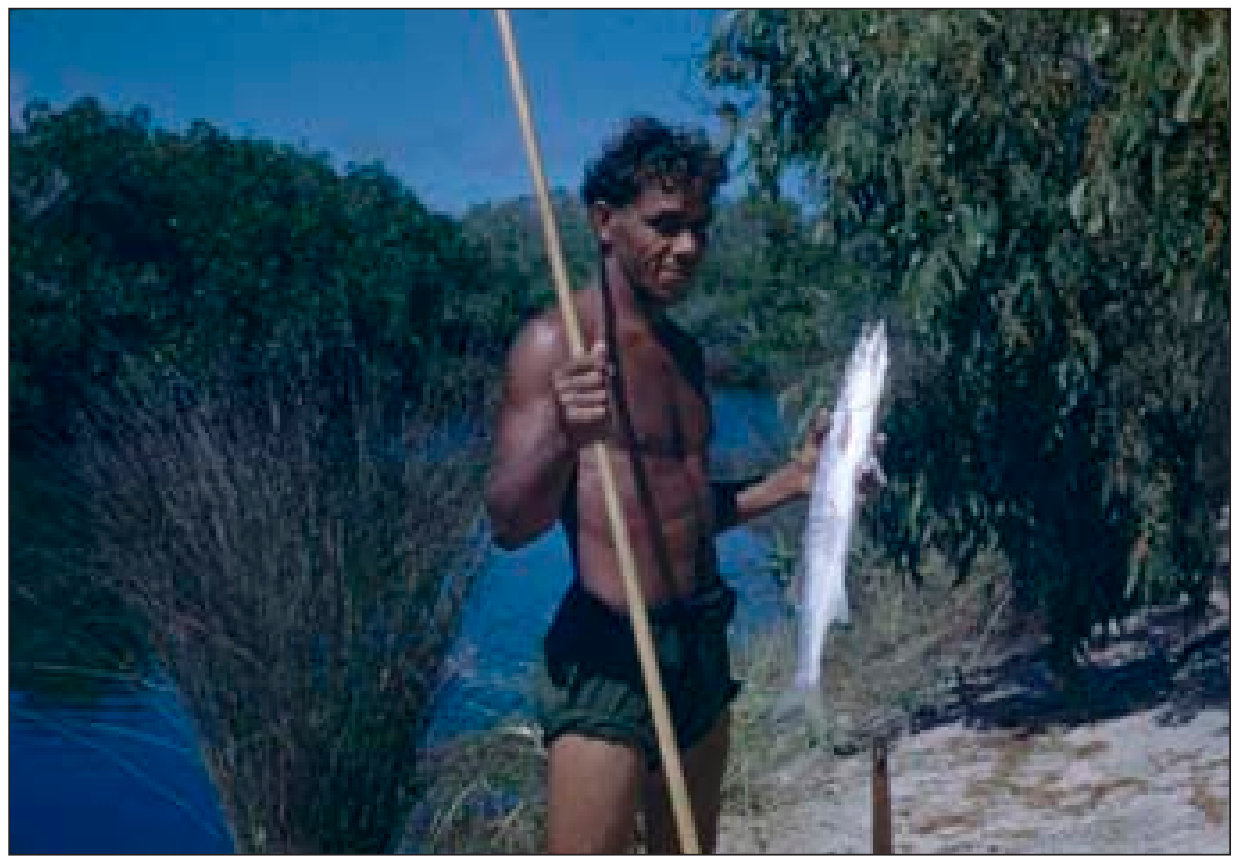

Figure 14.7 Gerry Blitner with spear and fish, Emerald River, Groote Eylandt, 5 June 1948

Photograph by R. R. Miller. By permission of the National Library of Australia.nla.pic-vn4515154. 


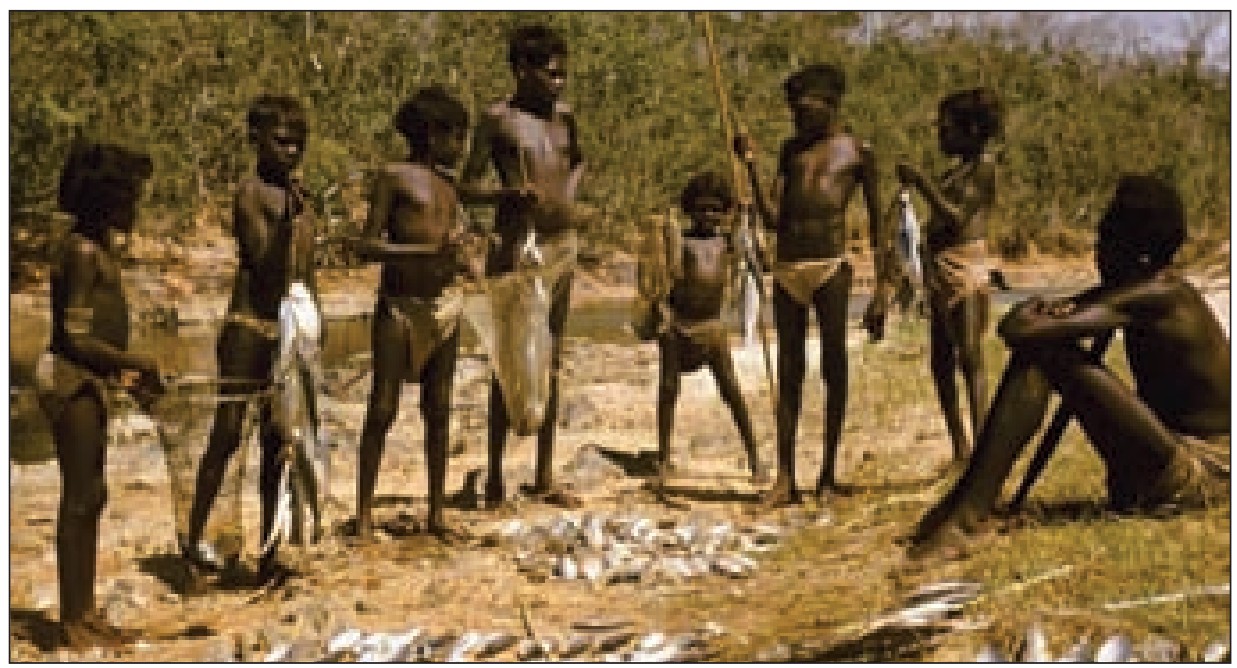

Figure 14.8 Aboriginal children and a man (names unknown) with their catch west of Yirrkala, 8 August 1948

Photograph by R. R. Miller. By permission of the National Library of Australia. nla.pic-vn4534255.

While Bob was in Arnhem Land, he received a letter from the University of Michigan offering him a position as Curator of Fishes in the Museum of Zoology - the position previously held by his PhD advisor, and now father-inlaw, Carl Hubbs. Bob considered the offer seriously. He was never particularly interested in marine fishes. In Bob's mind, there was only one global ocean, and the ability for fish to move freely around the world led to what he considered a less interesting taxonomic and evolutionary story. Marine ichthyologists would quickly disabuse Bob Miller's idea of marine fishes moving to wherever they liked; there are only a handful of marine species that are truly cosmopolitan. But the real appeal to Bob and other 'freshies' is that 42 per cent of all fish species are obligate freshwater taxa, despite the fact that only 0.01 per cent of all unfrozen water on Earth's surface is fresh. To Bob this meant there were intriguing questions for him to tackle in the fresh waters of the North American west. Indeed, through his 60-plus-year career, he never ran out of new ideas and interesting projects involving freshwater fishes. And he loved the arid south-west of the United States and Mexico, with the oddities of tiny fishes incongruously populating isolated springs in the desert. While still in Arnhem Land, Bob accepted the University of Michigan's offer. This meant that he would never be able to work up the extensive collection of marine, estuarine and freshwater fishes he had worked so hard to acquire. Identifying and writing up the results of the fish fauna of the Arnhem Land Expedition was left to William R. Taylor, who was hired by the Smithsonian Institution specifically to work on the Arnhem Land fish collections made by Bob and the Expedition in $1948 .{ }^{4}$ 
Although Bob Miller returned to Michigan and refocused his research efforts on the fish fauna of the western United States, Arnhem Land had exposed him to a moister environment than he had encountered in his earlier study of the deserts of the American south-west. He was impressed by the diversity of the rainforest fishes, which presented a stark contrast with the relatively small numbers of desert fish species. The Australian experience might well have motivated him to study the freshwater fishes of Mexico. Beginning in the mid-1950s, he led biannual field campaigns throughout Mexico, and he became the leading international expert on Mexican fishes. He wrote Freshwater Fishes of México, the definitive book on that large faunal region. ${ }^{5}$ Although Mexico is only onefifth the size of the continental United States, it is home to nearly two-thirds as many freshwater fishes as the United States and Canada combined. His book offers keys and distribution maps for more than 500 native species. The book and its accompanying illustrations and historical overview provide a synthesis of Mexican fishes and their current conservation status - similar in its goals in many respects to those of the Mountford-led Expedition to Arnhem Land 50 years earlier.

The Australian experience also imprinted on Bob the fragile relationship between the human enterprise and the distribution of plants and animals, especially the distribution of freshwater fishes. He was an early and ardent advocate for conservation, heralding the urgency in 1961 with a call to arms titled 'Man and the changing fish fauna of the American southwest'. ${ }^{6}$ He was a founding member of the Desert Fishes Council (Figure 14.9), chairing the organisation from 1974 until 1976. With his wife, Frances, and brother-in-law, Clark Hubbs, he wrote in the book Battle Against Extinction:

There are sound biological reasons for holding samples of virgin country in perpetuity. In time, most of the desert will be used by humans for one purpose or another-irrigation, grazing, mining, or playgroundsbut inevitably, scientists will need to know the original situation. A control is a basic part of every experiment. Retention of wilderness for the maintenance of biological diversity is a necessity for the survival of humans themselves. What we must avoid is a domesticated, homogeneous earth; for many it would be a far less fascinating place to live. ${ }^{7}$

5 Miller, R. R., Minckley, W. L. and Norris, S. M. 2006, Freshwater Fishes of México, University of Chicago Press, Ill. This was published posthumously with contributions from Minckley and Norris.

6 Miller, R. R. 1961, 'Man and the changing fish fauna of the American southwest', Papers of the Michigan Academy of Science, Arts \& Letters, vol. 46, no. 365.

7 Miller, R. R., Hubbs, C. and Miller, F. H. 1992, 'Ichthyological exploration of the American west: the Hubbs-Miller era, 1915-1950', in W. L. Minckley and J. E. Deacon (eds), Battle Against Extinction: Native fish management in the American west, University of Arizona Press, Tucson, pp. 19-40. 


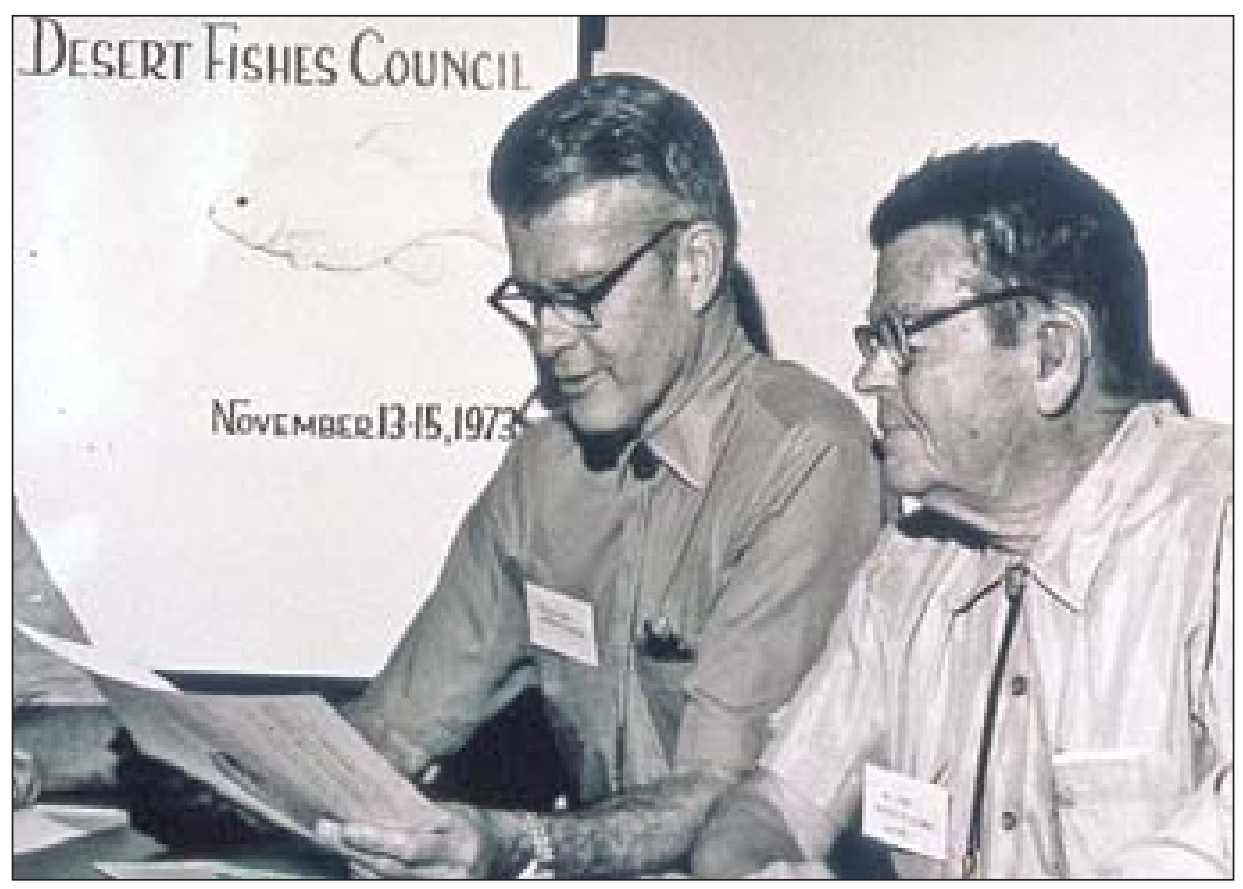

Figure 14.9 Miller and Carl Hubbs in Tempe, Arizona, at the Desert Fishes Council meeting in November 1973

By permission of the Desert Fishes Council Archives.

And, in 1989, he documented the sad litany of fish extinctions in 'Extinctions of North American fishes during the past century'. ${ }^{8}$

The influence of the Arnhem Land Expedition was not limited to his professional life. It also rippled through his family, especially his two oldest children, Frances and Gifford, both of whom were small children when Bob was on the Expedition (four and two years of age, respectively). Tokens of Australia were conspicuously displayed in the Miller household until Bob's death in 2003, with stories of the Expedition common fare around the dinner table. These constant reminders made strong impressions on the children. There is no doubt that this contributed to both Frances's and Gifford's desires to travel to exotic places such as Africa, Alaska, Arctic Canada and, eventually, Australia. Frances, a zoologist specialising in primate behavioural studies, did her dissertation research in the forests of Equatorial Guinea. Gifford became a geologist, specialising in climate change of the Quaternary - the most recent

8 Miller, R. R., Williams, J. D. and Williams, J. E. 1989, ‘Extinctions of North American fishes during the past century', Fisheries, vol. 14, pp. 22-48. 
geological era, encompassing the past several hundred thousand years. And although his dissertation research was conducted in the Canadian Arctic, he eventually found a route to a research program in Australia.

In fact, Bob Miller's most enduring Australian legacy from the Arnhem Land Expedition might be that both Frances and Gifford spent extended times in Australia and became involved in Australian research. This legacy extended yet another generation. Bob Miller's granddaughter, Mollie Cashner, after accompanying her grandfather to the fiftieth Arnhem Land Reunion in Sydney in 1998, was inspired to study fish, and has recently completed her $\mathrm{PhD}$ in ichthyology. She has a postdoctoral position at Southeastern Louisiana University.

Robert and Frances Cashner (Bob's son-in-law and daughter) and their two younger daughters, Mollie and Emily, first came to Australia in late January 1991. An Australian colleague, Donald Gartside, helped arrange positions for both Robert and Fran at Southern Cross University, in Lismore, New South Wales. Fran taught introductory biology classes and oversaw the related laboratories, while Robert undertook a research project on the NymboidaMann River - a major tributary of the Clarence River basin. His study resulted in an honours thesis and a publication in the Proceedings of the Linnaean Society of New South Wales. The Cashner family's stay was over in mid-August; no-one wanted to go home. Mollie returned four years later to do an undergraduate research project on wattlebirds in Melbourne. Both Emily and Mollie have made return trips with their parents. Fran made at least 11 trips to Australia and Robert 16. During one of those return trips, an exchange program was established between undergraduate students at Southern Cross and the University of New Orleans, where both Robert and Fran taught. Although the havoc wreaked by Hurricane Katrina in New Orleans caused this very successful exchange program to be suspended, it could soon be re-established.

Gifford has visited Australia most years since the late 1980s, including three year-long sabbaticals at the Australian National University (ANU) with his wife, Midra. Although he is a geologist by training, his research in collaboration with John Magee of the ANU on the evolution of the Australian summer monsoon has developed into a broader research campaign that seeks to unravel the footprints of human colonisation on the Australian continentin particular, to explain the demise of the Australian mega-fauna. The topic bridges his father's biological background and close association with Aboriginal groups during the Arnhem Land Expedition with the classical methods of geological investigation. In this research, Gifford continues the core thread of the scientific questions that motivated the original Arnhem Land Expedition. How did Aboriginal groups extract a living from the Australian landscape, especially in the early centuries after initial colonisation of the 
continent? And in the process, how did the Australian landscape respond to that activity? These questions remain alive in the contemporary world as we ponder how humans everywhere fit into their landscape and how we can manage a sustainable future. The published results of this research have revitalised the debate over the causes of mega-faunal extinction and climate change in Australia, including four articles in the two leading international scientific journals: Science and Nature. ${ }^{9}$

\footnotetext{
9 Miller, G. H., Magee, J. W. and Jull, A. J. T. 1997, 'Low-latitude glacial cooling in the southern hemisphere from amino acid racemization in emu eggshells', Nature, vol. 385, pp. 241-4; Miller, G. H., Magee, J. W., Johnson, B. J., Fogel, M., Spooner, N. A., McCulloch, M. T. and Ayliffe, L. K. 1999, 'Pleistocene extinction of Genyornis newtoni: human impact on Australian megafauna', Science, vol. 283, pp. 205-8; Johnson, B. J., Miller, G. H., Fogel, M. L., Magee, J. W., Gagan, M. K. and Chivas, A. R. 1999, ‘65,000 years of vegetation change in Central Australia and the Australian summer monsoon', Science, vol. 284, pp. 1150-2; Miller, G. H., Fogel, M. L., Magee, J. W., Gagan, M. K., Clarke, S. and Johnson, B. J. 2005, 'Ecosystem collapse in Pleistocene Australia and a human role in megafaunal extinction', Science, vol. 309, pp. 287-90.
} 